\title{
THE BASIS OF SECURITY
}

\section{FOR \\ NATIONAL, BANK NOTES.}

The probiem of how to provide a safe, uniform and elastic paper currency is the prominent financial question of the day. The business of banking has, in this country and under our legislation, been for so many years managed by institutions having charters from State or Federal governments, that even in the minds of thoughtful men some confusion has arisen as to the functions of a bank. The need which first created the banks, or called into existence bankers as a prominent class, was the kind of business which is now done by banks of discount and deposit.

"A banking business," says one of the thoughtful men now writing and speaking upon financial topics, "is the buying, selling and loaning of property, not paper." We have added to this the original and true function of a bank, the additional function of issuing its promissory notes which pass current from hand to hand and, while not actually money, are practically considered and treated as money, and furnish a large part of that circulating medium with which the transactions of individuals are settled. This feature of the banking business has become, not the most important, but the most widely discussed and dwelt upon, and has absorbed public attention until now, when the currency question is becoming the most prominent of our public questions, public attention is almost solely drawn to the function of a bank as one of issue, and in talking of banks and banking in our legislative halls it is the only one that attracts attention.

Before attempting at all to outline a method by which a banking currency can be established and satisfactorily maintained, a few preliminary thoughts may properly be set down as guides in determining the safety and soundness of any proposed plan for securing banking circulation.

[597] 
A bank of discount and deposit attracts to itself business by the credit which it has from its paid-up capital, and from the confidence of the community in the integrity and ability of its managing officers. The individuals who deposit with such a bank do so with the understanding that the funds that they deposit will be honestly and intelligently loaned to such an extent as experience demonstrates is safe, and that a sufficient reserve of such deposits will be at all times kept, so that the easily ascertained average of the drawings of the deposits upon the bank will be immediately paid. Against losses occasioned by mismanagement or errors in judgment or possible peculation, the depositor properly relies upon the credit of the bank resulting from its paid-up capital. The depositors in a bank of this character comprehend that the aggregate of their deposits is much larger in amount than the capital stock of the bank, and is secured by the capacity and fairness of the management of the bank, and that its capital is only the guarantee fund put up by the stockholders of the bank to induce credit, and to secure against losses for which the officers of the bank may be not at all blameworthy. This class of creditors are voluntary creditors, and avail themselves of the convenience of the bank upon the contract requiring of the bank, as is well understood, not that it shall keep the particular moneys they deposit or an equivalent amount of money on hand, but only such amount as will meet the average drawings, a percentage which is readily ascertained by brief experience.

When such a bank takes upon itself the further function of a bank of issue, it assumes liabilities to another and larger class of creditors, and practically, in many instances, to an entirely involuntary class of creditors. For while there is no legal compulsion upon any man to accept a bank note in payment of what is due him, or for property with which he parts at the time of payment, still in any business community the man who declines to receive the circulating notes of a solvent bank will very soon find himself isolated 
and his business opportunities limited, if not entirely destroyed. Practically it is that large class in the community who literally earn their bread in the sweat of their brow, and whose daily labor must meet their daily want, who are universally subject to such compulsion.

All civilized nations have assumed to regulate in one way or another the issuing of obligations intended to circulate as money, and have permitted such issue only upon terms and conditions intended to give security to the large class of involuntary creditors of the bank, who by their necessities and education are at once unable to refuse to receive the currency issued by the bank, and unfit to determine its value. This class of creditors practically constitute the general public, and this sort of legislation is intended for the protection of that public. Without stopping to inquire as to the natural source of authority for the enactment of such laws it is sufficient to take notice of their universality and of the fact that all bank note issues purport to be made by and under the sovereign authority of the State.

The original capital of the bark as subscribed and paid in constitutes the basis of credit with both classes of its creditors, the depositors and the noteholders, and the issue of bank notes under any system which has proven at all successful has been limited by the amount of the capital, sometimes to a greater and sometimes to a lesser percentage of it. The notes being payable on presentation and circulating freely among the people as money, and performing its function, have uniformly been recognized as a paramount obligation.

It has also been deemed essential both to the safety of the notes and to the accomplishment of the purposes for which they are issued that in some definite way the bank should secure by a deposit placed beyond its own control the payment of its notes. This result has been reached by the requirement for the deposit in the hands of the government itself, or the keeping under governmental supervision of gold or silver or securities in amounts sufficient to meet and to pay 
off these obligations, irrespective of the general funds of the bank, and beyond the reach of any calamity that may destroy its general solvency.

A further safeguard has been thrown around these notes by requiring repeated investigations of the condition of the bank by disinterested public officials, and by the publication of detailed statements of its condition. None of these things are required of the mere banker doing a private business as a bank of discount and deposit, but all of them are deemed requisite in the case of bank corporations existing under governmental authority, and doing business as banks of issue. The purpose is first to render the notes secure, and second, to so completely satisfy the community with the security of those notes as to make their free circulation possible.

The difficulty in framing a law which shall secure the circulation of a bank is in so adjusting it that the notes shall be secure to the holder, and their issue profitable to the bank. If the State should seize upon fifty per cent of the capital of the bank at its start and return the same or less amount of notes to the bank for circulation it is obvious that no possible profit could arise to the bank, and that it would be taking all the risk attendant upon the issue of circulation, and all the expense of handling and renewing it without any compensation, and that it might much more profitably loan its original funds in whatever form they were. Such a result would prevent the bank from taking out circulation. It is the approximation to such result which has caused the retirement of a large portion of national bank currency by the banks within the last ten years. Upon the other hand the delivery to the bank by the State of circulating medium in excess of its capital or without security purchased from such capital, and set apart for the protection of the notes, would leave the notes themselves with no fair basis of credit. The natural result would come, as it has come many times under various forms of "wild-cat" banking, and be the entire loss to the noteholders of the property for which they took the unsecured notes. Of necessity, therefore, and not 
from any desire to favor the banks, the security for bank circulation has been, under the most successful systems in this country, the use of a certain portion of the original capital of the bank for the purchase of approved securities, bearing interest, and the deposit of them witin some officer of the government, the government itself assuming the attitude of trustee for the bank and for the noteholder and holding the securities as protection to the noteholder until the notes are redeemed and then restoring them to the bank. This is the theory upon which the national banking system was based, and it has afforded, as all admit, a marvelously safe and uniform currency of equal value at the bank's counter or in the remotest corner of the land.

The rapid extingtishment of the public debt of the United States, and the high market price of its bonds, has brought about a condition where the taking of circulation by the national banks in many cases has ceased to be profitable, and in all cases affords but slight profit.

While we have not reached we have so nearly approached to the condition of things where the government simply takes from the bank a portion of its capital and returns to it a smaller amount of circulating notes that the extension of the system has been impeded, and were it not for other great advantages would have ceased. The approaching maturity of all the bonds of the United States, and the settled purpose of the people that this debt shall be paid, has caused the agitation for several years past of the question-What shall be done to perpetuate a system of banks of circulation? The financial condition of the country resulting from the agitation concerning the coinage of silver, and more recently from the preposterous plan of purchasing of silver bullion by the United States, and the outcry from the more remote sections of the country that they are suffering from loss of circulation resulting from the retirement of national bank notes, forces urgently upon our attention the question, what system of bank note circulation adequate to the needs of the country can be devised? 
Two methods of providing the currency demanded have come prominently to the front ; first, the return to the system of the issue of circulating notes by State banks; second, the perpetuation of the national banks, and the substitution of some other form of security for that at present used.

The definition of the requirements of a perfect form of paper currency, made by the late John Jay Knox, has always seemed to me entirely adequate. It was, "that the attributes of a perfect system of paper currency in this or any other country are: (I), safety ; (2), elasticity ; (3), convertibility ; (4), uniformity."

The two essential attributes of any such currency are: first, safety, and second, uniformity. The safety of any such currency must not only exist, but must be known to all men to exist. The citizens of California may be entirely certain of the safety of notes issued by banks under the laws of that State, but the citizen of Maine would assuredly be uninformed upon that subject. The safety of a bank note currency, known only to the skillful or the residents of the State in which the bank was located, would avail nothing in making such circulation answer the purposes of business to the unskilled inhabitants of other States. As the majority of the citizens of our country are, and are likely to remain, both unskillful and uninformed as to the laws of communities other than that in which they live, we should not, under a system of State banks, have that widely recognized safety in a bank note issued under State law, which is the primary and essential attribute of a sound paper currency did we depend upon the notes issued by banks regulated only by the law of the State in which they were located. Equally sure is it that we should have no uniformity in the safeguards thrown around such notes. The belief that such uniformity could be created by the legislation of forty-four independent States has been correctly designated as "utter folly." In the experience which I have had in examining the various systems of banking, proposed by members of the present House of Representatives, I find the irrefutable evidence of the widely [602] 
divergent ideas of different sections of the country upon this question of the proper method of issuing and securing paper money. In my judgment, the attempt to solve the problem of fumishing safe and uniform currency under the authority of forty-four different sovereignties might as well be abandoned at once. It failed before the war, and that failure was the result of the inevitable divergence of views upon this question between the different sections of the country. A system regulatad by the national government is the only one which can be relied upon to furnish a currency known by everybody to be safe and of uniform value throughout the length and breadth of the land.

Second. The suggestions with regard to the substitution of some other form of security for that at present used has divided itself broadly into two classes, (a) the creation of a safety fund, and (b) the substitution of other kinds of bonds for those of the Federal Grovernment.

Those who advocate the securing of national bank circulation for the future by a safety fund, urge it upon the attention of the country as being the more scientific method. Practically they make the circulating notes a first lien upon all the assets of the bank, and go to the safety fund only to make up the deficiency. There seem to me to be two objections to this method of securing the circulation. It deprives the banks of the fund which is the basis of its credit in asking for deposits. Without the deposit the banks cannot do a profitable business. It is difficult to believe that, the capital being subjected to a first lien for the amount of the notes, and there being always the possibility of an over-issue of such notes, the credit of the bank in its discount and deposit business would not be impaired. It is calling upon the capital to do a double work when it is already loaded with the single task of inspiring confidence in the people who have to make deposits.

Then, too, it imposes upon solvent and well-managed banks burdens from which they reap no direct benefit and pays a premium upon bad management. A bank which is well [603] 
managed and is making money as a bank of discount and deposit will have but slight, if any, inducement to go into a system which enables it to issue circulation, for which it has but little need if, by so doing, it is compelled to pay out of its earnings and profits for the losses occasioned by the bad management or conduct of the officials of some other institution over which it has no control. The result, it seems to me, would probably be that the banks which are best managed and strongest, and whose presence in any system is most desirable, would have the least temptation to go into it. The safety fund itself, on any system which has come under my notice, will have to be created after the notes are issued, and the notes may get into circulation and use before the security for their payment is called into being. The method may be as scientific as its advocates claim, but it does not seem to me to be practical.

The commonest form of objection to the substitution for national bonds of other securities as a basis of the issuing of bank note circulation, is that the Government of the United States ought not to guarantee the payment of notes based upon securities not its own. This objection is founded upon a mistake. The contract of guarantee is well understood to be a promise upon the part of some one other than the principal debtor to periorm his obligation. The Government of the United States has never made any such promise, and never ought to maike it. Its relation to the holders of national bank notes is purely that of trustee, and as such it should remain. Whatever the form of security used might be, the Government or its officers should hold those securities only to perform the promise of the Government to sell them and apply the proceeds as far as they go to the payment of the notes. That is all it now promises. That is as much as either the reason or the necessity of the case requires. The Government may as well hold other securities than its own as to hold the present class of securities for the purpose of performing that promise. 
Another objection to the substitution of any other class of securities is that their value is less certain. That objection is a valid one, as it seems to me, to the use of any promises to pay which are not enforceable by the exercise of the taxing power, and also of the securities issued by any community which has heretofore failed to perform, according to the letter, its contracts. State, county and municipal bonds of communities, which have not in recent years defaulted, are available, for this purpose. One advantage of their use, and particularly the use of the latter classes is that it makes available for banking purposes the credit of the very communities which need the circulation. With the increase of intelligence and wealth in all communities within our borders, with the more rapid and constant intercommunication between the different parts of the country the chances of any repudiation of obligations by State or smaller subdivisions of the country are very much lessened. The use of such securities as a basis of banking in the community issuing them would render practically impossible any repudiation. It is a comparatively easy matter to refuse to pay debts due to persons not living within the same community as the debtor, but the financial, social and political influence clustered about a bank renders practically impossible the repudiation by the community in which the bank exists of the obligations upon which the bank itself rests as the basis of its credit. It is true that these local securities, while equally valuable, might not be as readily convertible as federal bonds, and it is not improper that if they are to be used some method should be devised to furnish the means for the immediate redemption of the notes of every failed bank without using undue haste in realizing upon such forms of security.

I believe, therefore, that it is entirely safe to base an issue of bank circulation upon the security which would be offered, first, by the deposit in lieu of national bonds of State, county or municipal bonds; second, by making the bank note issue a first lien upon the assets of the [605] 
bank including the personal liability of the stockholder; and third, by creating a moderate sinking fund from which the notes could be redeemed at once upon the failure of the bank, provided that out of the other two classes of security the amount taken from the safety fund should be made good, less the amount contributed to it by the failed bank. Such a system would put the Government in funds to immediately redeem the notes; would afford the opportunity of holding the local securities until they could be safely and properly disposed of at fair price, and would render the notes themselves equally as good as those at present issued It is not open to the objection that the banks would be deprived of a portion of their capital without receiving any return therefor, because the bonds would bear interest. It would not seriously affect the credit of the bank with its depositors, because under proper regulation the securities deposited would certainly pay the notes, and hence no recourse to the general assets of the bank would ever become necessary. Nor would the better banks have the same ground for objection to a safety fund to be thus used, as to a general safety fund, because their proportion of it would never be used, except temporarily, to redeem the notes of any bank except their own. The advantages to them of a system, uniform all over the country, would be sufficient to compensate them for the loss of interest upon the money constituting their contribution to the safety fund. Whatever they did contribute would perpetually remain theirs, for the liquidation of their own obligations under any and all circumstances. Of course, details of the system, providing for entire publicity, thorough examination, for taxation and inexpensive redemption need to be added to the general features of this plan.

It should also be noted that there are yet fourteen years before the federal bonds can be paid off; that they may be as others have been, extended; and that the issue of other bonds by the federal government is a possibility unfortunately not remote nor improbable.

HENRY BACON.

House of Representatives, Waskington, D.C. 